\title{
Influence of the Carbon Source on Gordonia alkanivorans Strain 1B Resistance to 2-Hydroxybiphenyl Toxicity
}

\author{
Alexandra V. Teixeira • Susana M. Paixão • \\ Teresa Lopes da Silva $\cdot$ Luís Alves
}

Received: 23 January 2014 / Accepted: 2 April 2014 /

Published online: 13 April 2014

(C) Springer Science+Business Media New York 2014

\begin{abstract}
The viability of bacteria plays a critical role in the enhancement of fossil fuels biodesulfurization efficiency since cells are exposed to toxic compounds such as 2hydroxybiphenyl (2-HBP), the end product of dibenzothiophene (DBT) biodesulfurization. The goal of this work was to study the influence of the carbon source on the resistance of Gordonia alkanivorans strain 1B to 2-HBP. The physiological response of this bacterium, pregrown in glucose or fructose, to 2-HBP was evaluated using two approaches: a growth inhibition toxicity test and flow cytometry. The results obtained from the growth inhibition bioassays showed that the carbon source has an influence on the sensitivity of strain 1B growing cells to 2 -HBP. The highest $\mathrm{IC}_{50}$ value was obtained for the assay using fructose as carbon source in both inoculum growth and test medium $\left(\mathrm{IC}_{50}-48 \mathrm{~h}=0.464 \mathrm{mM}\right)$. Relatively to the evaluation of 2-HBP effect on the physiological state of resting cells by flow cytometry, the results showed that concentrations of $2-\mathrm{HBP}>1 \mathrm{mM}$ generated significant loss of cell viability. The higher the 2-HBP concentration, the higher the toxicity effect on cells and the faster the loss of cell viability. In overall, the flow cytometry results highlighted that strain $1 \mathrm{~B}$ resting cells grown in glucose- $\mathrm{SO}_{4}$ or glucose-DBT are physiologically less resistant to 2-HBP than resting cells grown in fructose- $\mathrm{SO}_{4}$ or fructose-DBT, respectively.
\end{abstract}

Keywords 2-Hydroxybiphenyl · Gordonia alkanivorans strain 1B · Biodesulfurization · Flow cytometry · Toxicity test

\section{Introduction}

Most of the industrial activities that our modern civilization depends upon use fossil fuels as the main source of energy, usually by burning [1]. This combustion causes air pollution due to emissions of sulfur dioxide, volatile organic compounds, and particulate matter, which contributes to the acidification of the atmosphere causing acid rain. These facts led to an increasingly stricter legislation that requires the reduction of sulfur levels in fossil fuels.

\footnotetext{
A. V. Teixeira $\cdot$ S. M. Paixão $(\square) \cdot$ T. L. da Silva $\cdot$ L. Alves $(\square)$

LNEG - Instituto Nacional de Energia e Geologia IP, Unidade de Bioenergia,

Estrada do Paço do Lumiar, 22, 1649-038 Lisbon, Portugal

e-mail: susana.alves@lneg.pt

e-mail: luis.alves@lneg.pt
} 